\title{
BDNF Is a Target-Derived Survival Factor for Arterial Baroreceptor and Chemoafferent Primary Sensory Neurons
}

\author{
Roseann Brady, Syed Ishrat Ali Zaidi, Catherine Mayer, and David M. Katz \\ Department of Neurosciences, Case Western Reserve University School of Medicine, Cleveland, Ohio 44106-4975
}

Brain-derived neurotrophic factor (BDNF) supports survival of $50 \%$ of visceral afferent neurons in the nodose/petrosal sensory ganglion complex (NPG; Ernfors et al., 1994a; Jones et al., 1994; Conover et al., 1995; Liu et al., 1995; Erickson et al., 1996), including arterial chemoafferents that innervate the carotid body and are required for development of normal breathing (Erickson et al., 1996). However, the relationship between BDNF dependence of visceral afferents and the location and timing of BDNF expression in visceral tissues is unknown. The present study demonstrates that BDNF mRNA and protein are transiently expressed in NPG targets in the fetal cardiac outflow tract, including baroreceptor regions in the aortic arch, carotid sinus, and right subclavian artery, as well as in the carotid body. The period of BDNF expression corresponds to the onset of sensory innervation and to the time at which fetal NPG neurons are BDNF-dependent in vitro. Moreover, baroreceptor innerva- tion is absent in newborn mice lacking BDNF. In addition to vascular targets, vascular afferents themselves express high levels of BDNF, both during and after the time they are BDNFdependent. However, endogenous BDNF supports survival of fetal NPG neurons in vitro only under depolarizing conditions. Together, these data indicate two roles for BDNF during vascular afferent pathway development; initially, as a target-derived survival factor, and subsequently, as a signaling molecule produced by the afferents themselves. Furthermore, the fact that BDNF is required for survival of functionally distinct populations of vascular afferents demonstrates that trophic requirements of NPG neurons are not modality-specific but may instead be associated with innervation of particular organ systems.

Key words: aortic arch; baroreceptor; baroreflex; BDNF; carotid body; carotid sinus; chemoreceptor; chemoreflex; neurotrophin; nodose ganglion; petrosal ganglion
Multiple growth factors are required to support development of the full complement of primary sensory neurons that innervate the cardiovascular, respiratory, and gastrointestinal systems. Thus, null mutations in the genes encoding brain-derived neurotrophic factor (BDNF; Ernfors et al., 1994a; Jones et al., 1994; Conover et al., 1995; Liu et al., 1995; Erickson et al., 1996), neurotrophin-3 (NT-3; Ernfors et al., 1994b; Farinas et al., 1994), neurotrophin-4 (NT-4; Conover et al., 1995; Liu et al., 1995; Erickson et al., 1996), and glial cell line-derived neurotrophic factor (Moore et al., 1996) all result in loss of 40-60\% of neurons in the nodose/petrosal sensory ganglion complex (NPG), the major source of visceral afferent innervation. The diversity of growth factor requirements in this system may be partially explained by sequential dependencies of some neurons on more than one factor. Specifically, NT-3 and NT-4 appear to act relatively early during NPG development compared with BDNF, suggesting that some neurons switch trophic dependence with age (ElShamy and Ernfors, 1997). On the other hand, $>90 \%$ of NPG neurons die in double bdnf/nt4 null mutants, and this loss is

Received Nov. 17, 1998; accepted Jan. 4, 1999.

This work was supported by a Public Health Service Grant (NHLBI) to D.M.K. We thank Dr. George Yancopoulos and his colleagues at Regeneron Pharmaceuticals for generously providing $b d n f$ and $n t 4$ mutant mice, TrkB-Fc, and the $b d n f$ plasmid used for making our cRNA probes, and Dr. Qiao Yan of Amgen for a generous gift of BDNF antibody. We also acknowledge the outstanding technical assistance of Mrs. Hua Jun He and thank Drs. Agnieszka Balkowiec, Jeffery Erickson, and Jerry Silver, and Teresa Brosenitsch, for thoughtful comments on this manuscript, and Dr. Stephen Davies for help with Figure 9.

The first two authors contributed equally to this study and are listed alphabetically.

Correspondence should be addressed to Dr. David M. Katz, Department of Neurosciences, Case Western Reserve University School of Medicine, 10900 Euclid Avenue, Cleveland, OH 44106-4975.

Copyright (C) 1999 Society for Neuroscience $\quad 0270-6474 / 99 / 192131-12 \$ 05.00 / 0$ virtually additive of the effects of single $b d n f$ or $n t 4$ homozygous mutations, indicating that BDNF and NT-4 support survival of largely nonoverlapping populations of neurons (Conover et al., 1995; Liu et al., 1995; Erickson et al., 1996).

Despite the fact that the NPG complex is one of the major sites of neuronal loss in BDNF, NT-3, and NT-4 null mutants, the relationship between growth factor dependence and the location and timing of neurotrophin expression in visceral target tissues is unknown. This issue is further complicated by findings that NPG neurons themselves express BDNF (Wetmore and Olson, 1995; Zhou et al., 1998) and that endogenous BDNF, acting in an autocrine or paracrine manner, can support survival of primary sensory neurons under some conditions in culture (Acheson et al., 1995; Robinson et al., 1996b). It is also unknown whether neurotrophin dependence is related to specific sensory modalities, as proposed for somatosensory neurons (Snider, 1994), or alternatively, to innervation of particular tissues or organ systems.

To approach these questions, the present study examined the relationship between BDNF expression in developing visceral targets and survival of visceral afferents, focusing in particular on arterial baroreceptor neurons. Baroreceptor afferents are mechanosensitive NPG neurons that innervate specialized regions of the cardiac outflow tract and respond to changes in arterial blood pressure (Abboud and Thames, 1983). Baroreceptor afferents play a critical role in cardiorespiratory homeostasis by buffering against rapid changes in arterial pressure (Abboud and Thames, 1983), and loss of baroreceptor function during development leads to increased variability in heart rate and blood pressure (Itskovitz et al., 1983; Yardley et al., 1983). However, mechanisms that underlie development of baroreceptor innervation are unknown. Baroreceptor neurons are particularly advantageous for 


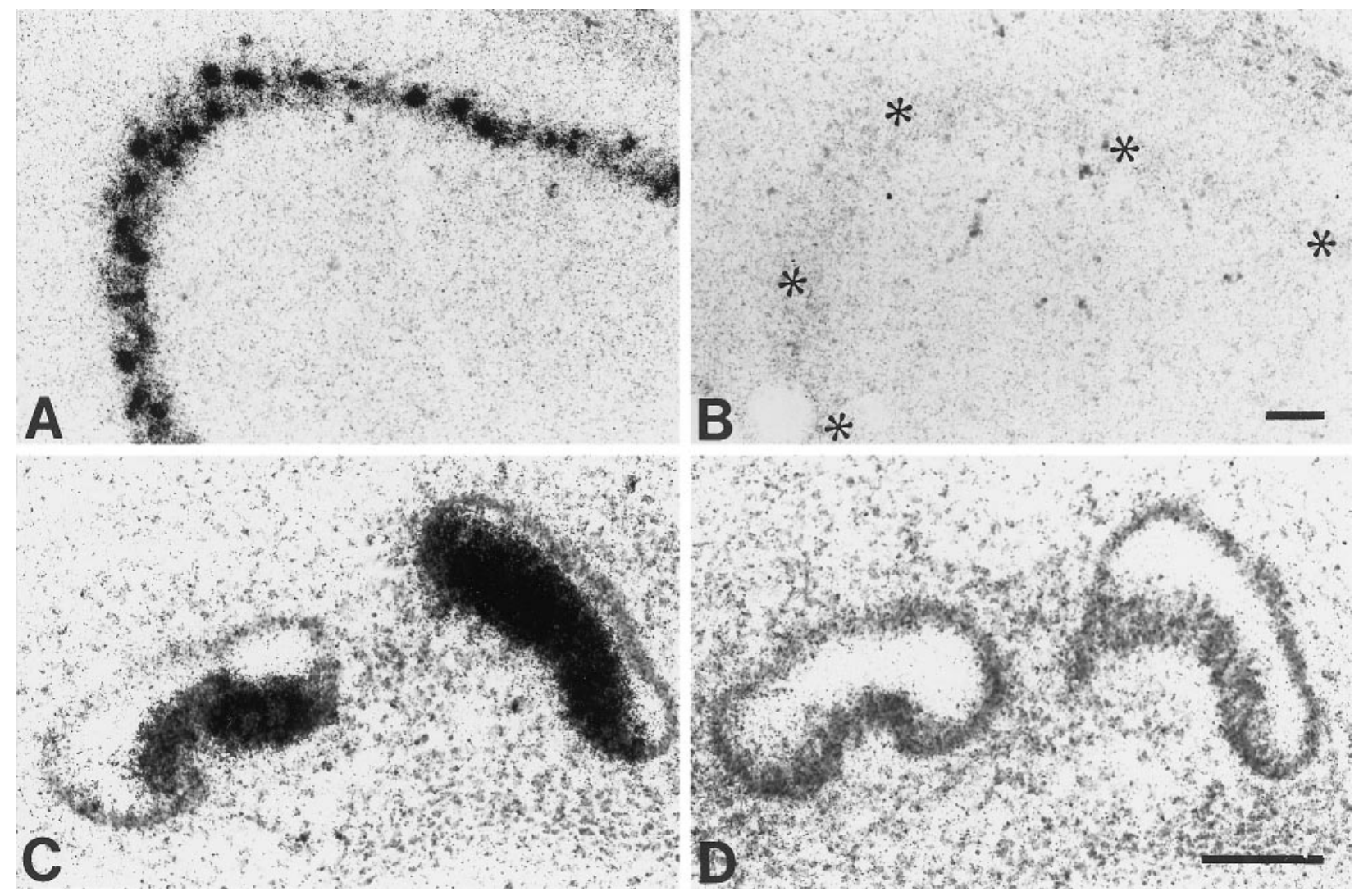

Figure 1. Localization of BDNF mRNA in control tissues. Photomicrographs showing localization of BDNF mRNA in the CA3 region of adult rat hippocampus $(A)$ and in E16.5 vestibular sensory epithelium $(C)$. Adjacent sections showing hybridization with sense cRNA probe $(B, D)$. Asterisks in $B$ indicate the CA3 region. Sections were counterstained with cresyl violet. Scale bars, $100 \mu \mathrm{m}$.

studies of this kind for two reasons. First, innervation of arterial baroreceptor targets is almost purely sensory and is therefore not confounded by the presence of parasympathetic fibers or intrinsic neurons, as in the other viscera. Second, we found previously that $\mathrm{BDNF}$ is required for development of another population of cardiovascular afferents, chemoafferent neurons innervating the carotid body (Erickson et al., 1996). Therefore, chemoafferent and baroreceptor neurons provide a model for examining whether BDNF dependence of NPG neurons is related to a particular sensory modality, such as chemosensation, or alternatively, to innervation of a particular organ system, such as the arterial vasculature.

\section{MATERIALS AND METHODS}

\section{Animals}

Pregnant Sprague Dawley rats were obtained from Zivic-Miller Laboratories (Zelienople, PA). Mice carrying targeted mutations in either the $b d n f$ or $n t 4$ gene (Conover et al., 1995) were initially provided by Regeneron Pharmaceuticals (Tarrytown, NY) and then bred in our institutional animal care facility.

\section{Tissue collection for histological procedures}

Newborn or postnatal day $0(\mathrm{P} 0)$ and 1-week-old (P7) rat and mouse pups were anesthetized with sodium pentobarbital ( $6 \mathrm{gm} / \mathrm{kg}$, i.p.), perfused transcardially with fixative (see below), and tissues were removed and post-fixed overnight. Fetuses were removed from pregnant dams that were killed with carbon dioxide and then fixed intact by immersion overnight. Two different fixatives were used depending on the histochemical procedure: for in situ hybridization and immunostaining with antiprotein gene product (PGP) 9.5 antibodies, the fixative was $4 \%$ paraformaldehyde (PFA) in $0.1 \mathrm{M}$ sodium phosphate buffer, $\mathrm{pH} 7.4$; for BDNF and tyrosine hydroxylase (TH) immunostaining, the fixative was $2 \%$ PFA in $0.07 \mathrm{M}$ sodium phosphate buffer, $\mathrm{pH} 7.2$, containing $0.2 \%$ parabenzoquinone (Conner et al., 1997). Intact fetuses and P0 and P7 tissue samples were cryoprotected in $30 \%$ sucrose in PBS, $\mathrm{pH} 7.4$, infiltrated with a 1:1 mixture of $30 \%$ sucrose-PBS and OCT embedding medium (Tissue-Tek OCT-4583; Baxter Scientific, McGraw Park, IL), embedded in OCT, frozen over dry ice, and cut in a cryostat (10 or $14 \mu \mathrm{m}$ sections). Tissues used for in situ hybridization were processed under RNase-free conditions.

\section{In situ hybridization}

Rat cDNA, encoding prepro-BDNF (bp 1-1085, GenBank accession number M61175; Maisonpierre et al., 1991) cloned into the EcoRI site of pBluescript SK $(-)$ phagemid (Stratagene, La Jolla, CA) and designated as BDNF[pSK-rB $(\mathrm{C} 1)]$ was a gift from Dr. G. D. Yancopoulos (Regeneron). The plasmid template was linearized by digestion with either XhoI or NotI to generate the corresponding sense and antisense transcripts, under the T3 or T7 promoter, respectively. The restriction digest DNA was treated with proteinase $\mathrm{K}$ and extracted with phenol-chloroform. cRNA probes were synthesized using an RNA transcription kit (Stratagene) as per the manufacturer's directions, in a reaction mixture containing $14 \mu \mathrm{Ci} / \mu \mathrm{l}\left[\alpha^{-}{ }^{35} \mathrm{~S}\right] \mathrm{CTP}$ (Dupont NEN, Boston, MA). The reaction product was treated with DNase, and the labeled cRNA probes were recovered by ethanol precipitation. The integrity of the probes was confirmed by electrophoresis and autoradiography.

Two sets of adjacent tissue sections were treated briefly with protease (125 $\mu \mathrm{g} / \mathrm{ml}$; Sigma, St. Louis, MO), acetylated with $0.25 \%$ (v/v) acetic anhydride in $0.1 \mathrm{M}$ triethanolamine- $\mathrm{HCl}$, and dehydrated through a graded series of ethanol. Alternate sections were then incubated overnight, either with sense or antisense probe $\left(80 \times 10^{3} \mathrm{dpm} / \mu \mathrm{l}\right)$ diluted in hybridization solution [20 mM Tris-HCl buffer, $\mathrm{pH} 7.4,0.5 \mathrm{mg} / \mathrm{ml}$ tRNA, $0.1 \mathrm{~m}$ DTT, $50 \%$ formamide, $0.3 \mathrm{M} \mathrm{NaCl}, 10 \mathrm{~mm} \mathrm{NaH}_{2} \mathrm{PO}_{4}, 5 \mathrm{~mm}$ EDTA, $10 \%$ dextran sulfate, and $1 \times$ Denhardt's solution (Sigma) $]$ at $55^{\circ} \mathrm{C}$ in a humidified chamber. After hybridization, the slides were washed for 30 min each in $5 \times \mathrm{SSC}(0.3 \mathrm{M} \mathrm{NaCl} / 0.03 \mathrm{M}$ sodium citrate, $\mathrm{pH} 7.0)$ and $2 \times$ SSC containing $10 \mathrm{~mm} \mathrm{DTT} \mathrm{at} 55^{\circ} \mathrm{C}$ and treated with RNase A and 

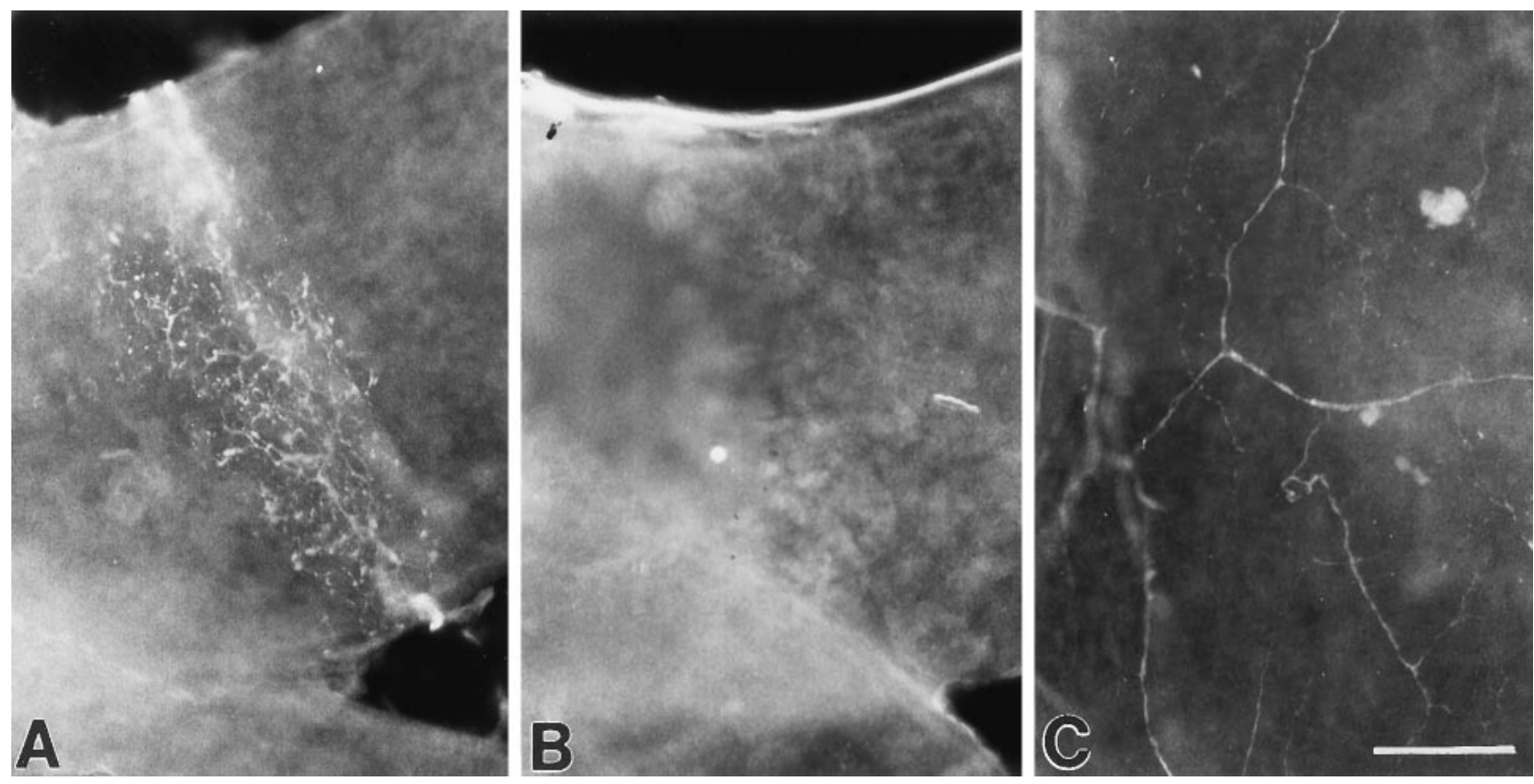

Figure 2. Baroreceptor innervation is absent in newborn bdnf-/- mice. Photomicrographs of PGP-immunostained, whole-mount preparations showing the presence $(A)$ and absence $(B)$ of baroreceptor fibers at the origin of the right subclavian artery in a wild-type and $b d n f-/-$ mouse, respectively. Sympathetic fibers are present $(C)$ in the aorta of the same $b d n f-/-$ preparation shown in $B$. Scale bar, $100 \mu \mathrm{m}$.

RNase T1. The slides were then washed for $30 \mathrm{~min}$ in $2 \times \mathrm{SSC}$ containing $50 \%$ formamide and $10 \mathrm{~mm}$ DTT at $65^{\circ} \mathrm{C}$ and twice for 30 min with $1 \times$ SSC containing $0.066 \%$ sodium pyrophosphate and $15 \mathrm{~mm}$ DTT at $55^{\circ} \mathrm{C}$. The sections were dehydrated through a series of graded ethanol $(30,60$, 80 , and $95 \%$ ) containing $0.3 \mathrm{M}$ ammonium acetate, then $100 \%$ ethanol, air-dried, exposed to radiographic emulsion (NTB2; Eastman Kodak, Rochester, NY) for 4 weeks, developed in D-19 (Eastman Kodak), counterstained with cresyl violet-acetate, and coverslipped with Permount (Fisher Scientific, Pittsburgh, PA).

To verify the specificity of our probes, alternate sections through the adult hippocampus and embryonic day 16.5 (E16.5) rat fetus were hybridized with antisense and sense cRNAs and analyzed for antisense labeling in areas previously shown to express BDNF mRNA. Hybridization of adult hippocampal sections with the antisense probe resulted in dense labeling of pyramidal cells in the CA2, CA3 (Fig. 1 $A$ ), and hilus regions with moderate labeling of CA1 pyramidal and dentate gyrus granule cells. This pattern corresponds to previous studies using different BDNF probes (Hofer et al., 1990; Wetmore et al., 1990; Conner et al., 1997). In E16.5 fetuses, the antisense probe densely labeled various neural and non-neural tissues previously shown to express BDNF mRNA, including lingual papillae (Nosrat and Olson, 1995) and dorsal root ganglia (Ernfors et al., 1992; Schecterson and Bothwell, 1992) and the sensory epithelium in the vestibular labyrinth (Fig. 1C; Ernfors et al., 1992; Pirvola et al., 1992; Ylikoski et al., 1993; Schecterson and Bothwell, 1994). No signal was detected above background levels in adult hippocampus or E16.5 fetuses after hybridization with the sense probe (Fig. $1 B, D$ ).

\section{Immunocytochemistry}

PGP 9.5, neurofilament, and TH immunostaining. Tissue sections and cultures were stained as previously described (Erickson et al., 1996) using the following antisera: (1) rabbit anti-PGP 9.5 (1:1000; Accurate, Westbury, NY), (2) mouse anti-neurofilament $\left(\mathrm{NF}_{68,160}, 1: 100\right.$; Sigma), (3) rabbit anti-TH (1:200; Pel-Freez Biologicals, Rogers, AR), (4) goat anti-rabbit IgG-FITC (1:200; Boehringer Mannheim, Indianapolis, IN), or (5) goat anti-mouse IgG-rhodamine (1:200; Organon Teknika Cappel, Durham, NC). Whole-mount preparations were permeabilized in dilution buffer (DB; $0.02 \mathrm{M} \mathrm{NaH}_{2} \mathrm{PO}_{4}, 0.02 \mathrm{M} \mathrm{Na}_{2} \mathrm{HPO}_{4}, 0.5 \mathrm{M} \mathrm{NaCl}, 0.3 \%$ Triton $\mathrm{X}-100$, and $2 \% \mathrm{BSA}, \mathrm{pH} 7.4$ ) containing an additional $0.6 \%$ Triton X-100.

$B D N F$ immunostaining. Tissues were stained with rabbit anti-BDNF (1:2000; Amgen, Thousand Oaks, CA) or double-stained with antiBDNF and mouse anti-TH (1:500; Incstar, Stillwater, MN) as described below. The BDNF antibody does not cross react with NGF, NT-3, or NT-4 and does not stain brain tissue sections taken from BDNF knockout mice (Yan et al., 1997b). BDNF staining was amplified using the Tyramide signal amplification kit (TSA-indirect kit; NEN Life Science Products, Boston, MA). Sections were (1) quenched with $0.5 \% \mathrm{H}_{2} \mathrm{O}_{2}$, washed in DB for $1 \mathrm{hr}$, blocked with avidin and biotin (Vector Laboratories, Burlingame, CA) for $15 \mathrm{~min}$, then washed again in DB; (2) incubated overnight at room temperature with anti-BDNF alone or in combination with anti-TH, in DB containing $10 \%$ goat serum; (3) washed in $\mathrm{DB}$ and incubated with biotinylated goat anti-rabbit IgG $(1: 200$; Vector Laboratories, diluted in PBS containing 10\% goat serum) for 30 min; (4) washed in PBS and incubated for 30 min with ABC Elite reagent (1:100 in $0.5 \mathrm{M} \mathrm{NaCl-PBS,} \mathrm{Vector} \mathrm{Laboratories);} \mathrm{(5)} \mathrm{washed} \mathrm{in} 0.5 \mathrm{M}$ $\mathrm{NaCl}-\mathrm{PBS}$ followed by Tris buffer $(0.1 \mathrm{M}$ Tris- $\mathrm{HCl}, 0.15 \mathrm{M} \mathrm{NaCl}$, and $0.5 \%$ Tween 20) and incubated for 4 min in biotinyl Tyramide solution (1:50, TSA kit); and (6) washed in Tris buffer $(0.15 \mathrm{M} \mathrm{NaCl}$ in $0.1 \mathrm{M}$ Tris-HCl) and then rinsed in Tris buffer containing blocking reagent (TSA kit) for $10 \mathrm{~min}$. For immunoperoxidase staining, the sections were incubated for $30 \mathrm{~min}$ in $\mathrm{ABC}$ Elite reagent (1:50), washed with $0.5 \mathrm{M}$ $\mathrm{NaCl}-\mathrm{PBS}$, washed with PBS, and reacted with $0.4 \%$ 3,3' diaminobenzidine tetrahydrochloride diluted in PBS containing $0.03 \% \mathrm{NiCl}_{2}$ and $0.008 \% \mathrm{H}_{2} \mathrm{O}_{2}$. For immunofluorescence staining, the sections were incubated for $1 \mathrm{hr}$ in streptavidin-FITC (1:100; Molecular Probes, Eugene, $\mathrm{OR}$ ) instead of the second treatment with $\mathrm{ABC}$ Elite reagent, then washed in PBS, treated with $\rho$-phenylenediamine and coverslipped with glycerol gel. For BDNF/TH double-labeling, sections were first incubated at step 3 above in goat anti-mouse Cy3 (1:200; Jackson ImmunoResearch, West Grove, PA) for $1 \mathrm{hr}$, washed in DB, and then processed as described for single-labeling. Control sections were stained as described above, except that the primary antibody was omitted (see Fig. 8).

Histochemical staining for acetylcholinesterase was performed as previously described (Katz and Karten, 1985).

\section{Cell cultures}

Pregnant dams were killed by exposure to carbon dioxide, and P0 rat pups were deeply anesthetized with sodium pentobarbital and then decapitated. Petrosal ganglia were removed from E16.5 fetuses and newborn pups and washed in $\mathrm{Ca}^{2+}$ - and $\mathrm{Mg}^{2+}$-free PBS (Life Technologies, Gaithersburg, MD). Ganglia were digested in either dispase (E16.5 ganglia; Collaborative Biomedical Products, Bedford, MA) or $0.25 \%$ trypsin (P0 ganglia; Worthington Biochemicals, Lakewood, NJ) diluted 

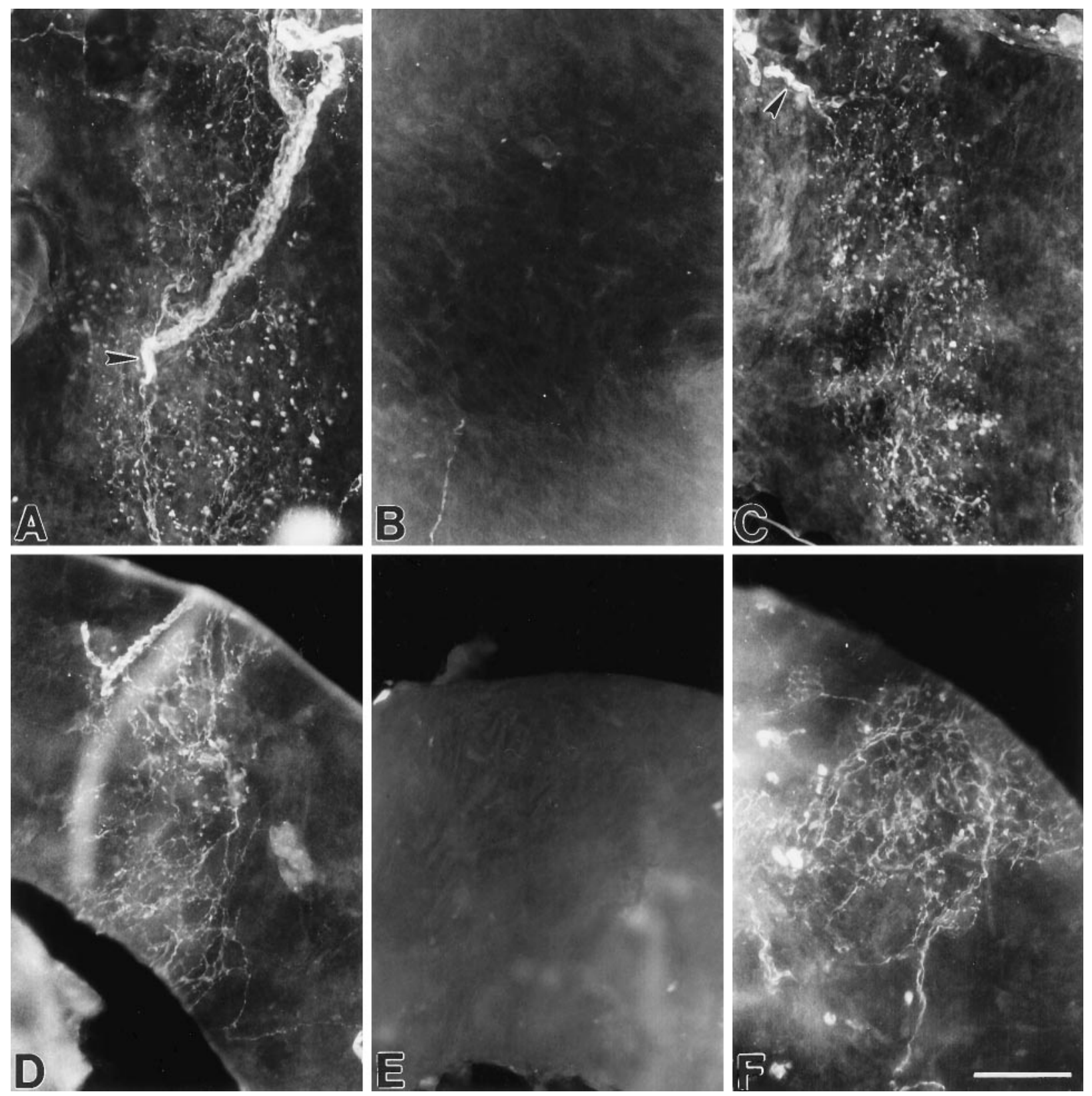

Figure 3. Baroreceptor innervation is absent in newborn $b d n f-/-$ mice and present in $n t 4-/-$ mice. Photomicrographs showing localization of PGP immunoreactivity in whole-mount preparations of the aortic arch $(A-C)$ and carotid sinus $(D-F)$ in wild-type $(A, D), b d n f-/-(B, E)$, and $n t 4-/-(C$, $F)$ mice. In wild-type mice, the aortic arch $(A)$ and carotid sinus $(D)$ are densely innervated by baroreceptor fibers and punctate terminal swellings. Baroreceptor fibers and terminals are absent in the aortic arch $(B)$ and carotid sinus $(E)$ of $b d n f-/-$ mice and are present in $n t 4-/-$ mice, $C$ and $F$, respectively. Arrowheads in $A$ and $C$ point to the incoming aortic depressor nerve fiber bundle that is mostly outside the field of view in $C$. Scale bar, $100 \mu \mathrm{m}$.

in $\mathrm{Ca}^{2+}$ - and $\mathrm{Mg}^{2+}$-free $\mathrm{PBS}$ for $35 \mathrm{~min}$ at $37^{\circ} \mathrm{C}$ followed by trituration through fire-polished Pasteur pipettes. Cells were plated at a density of one ganglion per well onto glass coverslips coated with poly-D-lysine $(0.1$ $\mathrm{mg} / \mathrm{ml}$, Sigma) and laminin $(0.3 \mathrm{mg} / \mathrm{ml}$, Sigma $)$. Cultures were grown in Leibovitz's L-15/ $\mathrm{CO}_{2}$ medium containing $10 \%$ NuSerum (Collaborative), $5 \%$ heat-inactivated rat serum, fresh vitamin mixture (Mains and Patterson, 1973), penicillin (50 IU/ml, Life Technologies), and streptomycin $(50 \mu \mathrm{g} / \mathrm{ml}$, Life Technologies) for $3 \mathrm{~d}$ in the absence or presence of either recombinant BDNF (10 ng/ml; Regeneron), TrkB-Fc $(5 \mu \mathrm{g} / \mathrm{ml}$, Regeneron), elevated $\mathrm{KCl}$ (40 mM final concentration), or $40 \mathrm{~mm} \mathrm{KCl}$ plus TrkB-Fc. Cultures were stained with either anti-neurofilament (E16.5) or anti-PGP (P0) antibodies to visualize neurons. Neuron numbers were obtained by counting all neurofilament-positive or PGPpositive cells per culture. Statistical analysis was performed using
ANOVA followed by Scheffé's multiple comparison procedure. $p$ values $<0.05$ were considered significant.

\section{RESULTS}

\section{Vascular afferent survival in bdnf and $n t 4$ null mutant mice}

We previously found that targeted disruption of $b d n f$, but not $n t 4$, alleles leads to death of chemoafferent neurons that innervate the carotid body (Erickson et al., 1996). To determine whether baroreceptor afferents are also BDNF-dependent, we examined innervation of the principal baroreceptor regions of the cardiac outflow tract, i.e., the aortic arch, carotid sinus, and the origin of the right subclavian artery, in whole-mount 

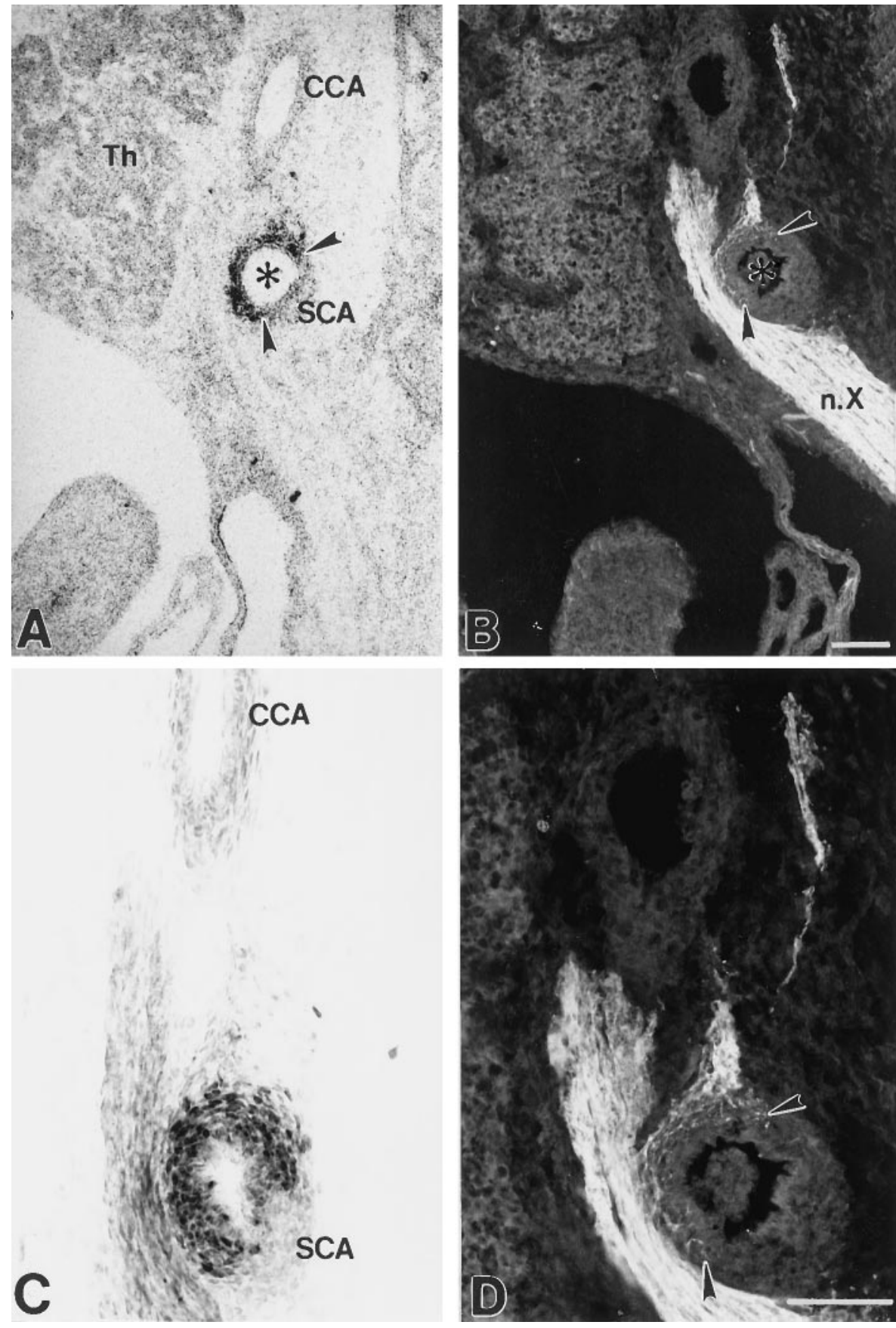

Figure 4. Localization of BDNF mRNA and protein, and baroreceptor fibers in the fetal right subclavian artery (ventral aspect). Photomicrographs showing localization of BDNF mRNA $(A)$, BDNF immunoreactivity $(C)$, and PGPstained baroreceptor fibers $(B$, and at higher magnification in $D$ ) in sagittal sections through the origin of the right subclavian artery at E16.5. The circumferential distribution of baroreceptor innervation ( $B, D$, arrowheads) corresponds to the distribution of BDNF mRNA ( $A$, arrowheads) and protein $(C)$. In all sections in this and subsequent figures, rostral is $u p$ and dorsal is to the right. Sections in $A$ and $C$ were counterstained with cresyl violet. $A A$, Aortic arch; $C C A$, common carotid artery; $S C A$, subclavian artery; $T h$, thymus; $n . X$, vagus nerve. Scale bars, $100 \mu \mathrm{m}$. preparations from newborn wild-type, bdnf null, and nt4 null mutant mice. In samples from wild-type animals $(n=8)$, a dense plexus of highly arborized fibers and flattened terminal swellings, characteristic of baroreceptor innervation (Heymans and Neil, 1958), was present at the origin of the right subclavian artery (Fig. $2 A$ ) in the aortic arch (Fig. $3 A$ ) and carotid sinus (Fig. $3 D$ ). In contrast, all samples from $b d n f-/-$ animals $(n=10)$ were devoid of baroreceptor innervation (Figs. $2 B$, $3 B, E)$. Sympathetic innervation to the vessels, however, was intact (Fig. $2 C)$. In $n t 4$ null mutants $(n=4)$, on the other hand, the pattern and density of baroreceptor innervation was indistinguishable from wild-type controls (Fig. $3 C, F$ ). To rule out the possibility that the lack of fiber staining in bdnf null mutants was caused by downregulation of PGP immunoreactivity rather than loss of fibers, additional samples were stained for two other neuronal markers, acetylcholinesterase and neurofilament proteins. Again, baroreceptor innervation was present in samples from wild-type $(n=4)$, but not $b d n f-/-(n=8)$ mice (data not shown).

\section{Localization of BDNF mRNA and protein in baroreceptor regions of the fetal vasculature}

To define the relationship between BDNF dependence of baroreceptor neurons and developmental expression of BDNF, we examined the distribution of BDNF mRNA and protein in the vasculature of fetal rats using in situ hybridization and immunocytochemistry, respectively, and compared these data with the timing and location of baroreceptor innervation using immunocytochemical staining for PGP 9.5 to identify nerve fibers.

BDNF mRNA and protein, as well as nerve fibers, were undetectable within any baroreceptor regions before E14.5. However, between E14.5 and 16.5, high levels of BDNF mRNA and protein appeared in all of the principal arterial baroreceptor regions, including the right subclavian artery at its origin from the brachiocephalic trunk (Figs. $4 A, C, 5 A, C$ ), the aortic arch (Fig. 6A,C), and the carotid sinus (Figs. 7 $A, B, 8 A$ ), coincident with the appearance of baroreceptor fibers. There was a 

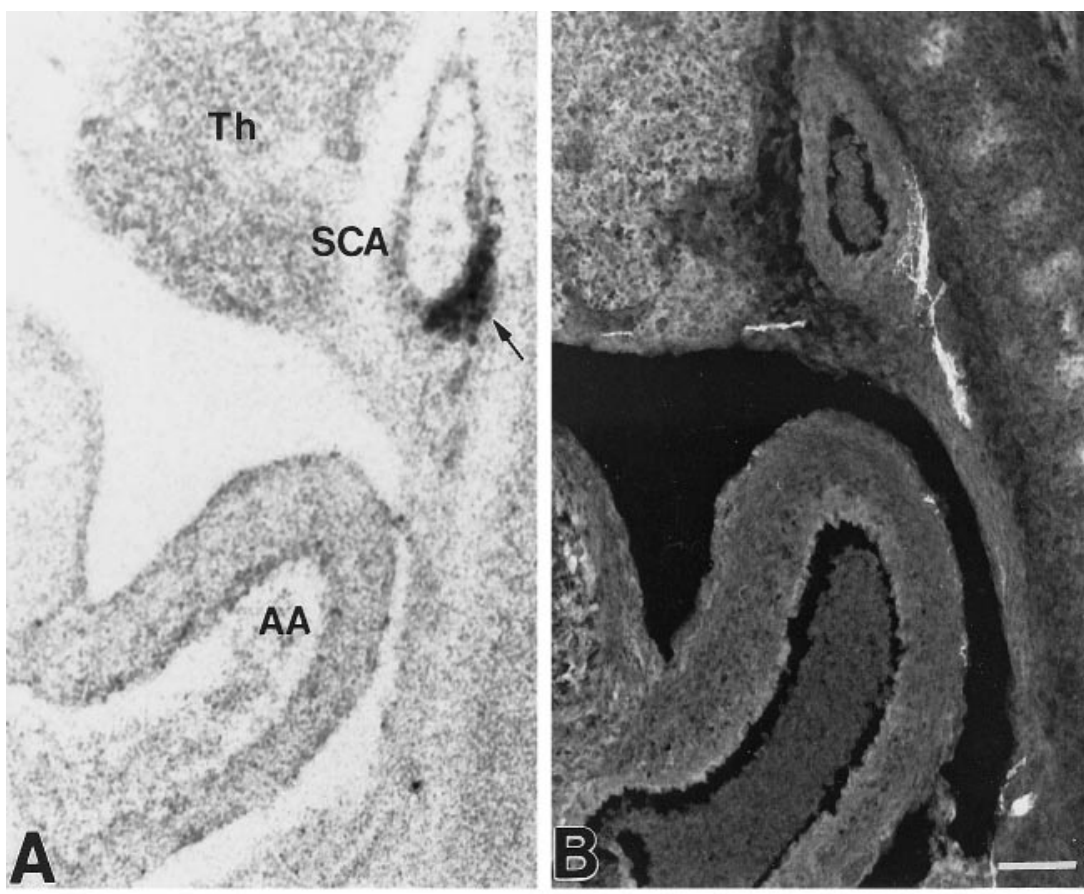

Figure 5. Localization of BDNF mRNA and protein, and baroreceptor fibers in the fetal right subclavian artery (dorsal aspect). Photomicrographs showing localization of BDNF mRNA ( $A$, arrow), BDNF immunoreactivity $(C$, arrow), and PGP-stained baroreceptor fibers $(B$, and at higher magnification in $D$ ) in sagittal sections through the origin of the right subclavian artery at E16.5. The level depicted in these sections is medial to that shown in Figure 4. Sections in $A$ and $C$ were counterstained with cresyl violet. Abbreviations and scale bars as in Figure 4.
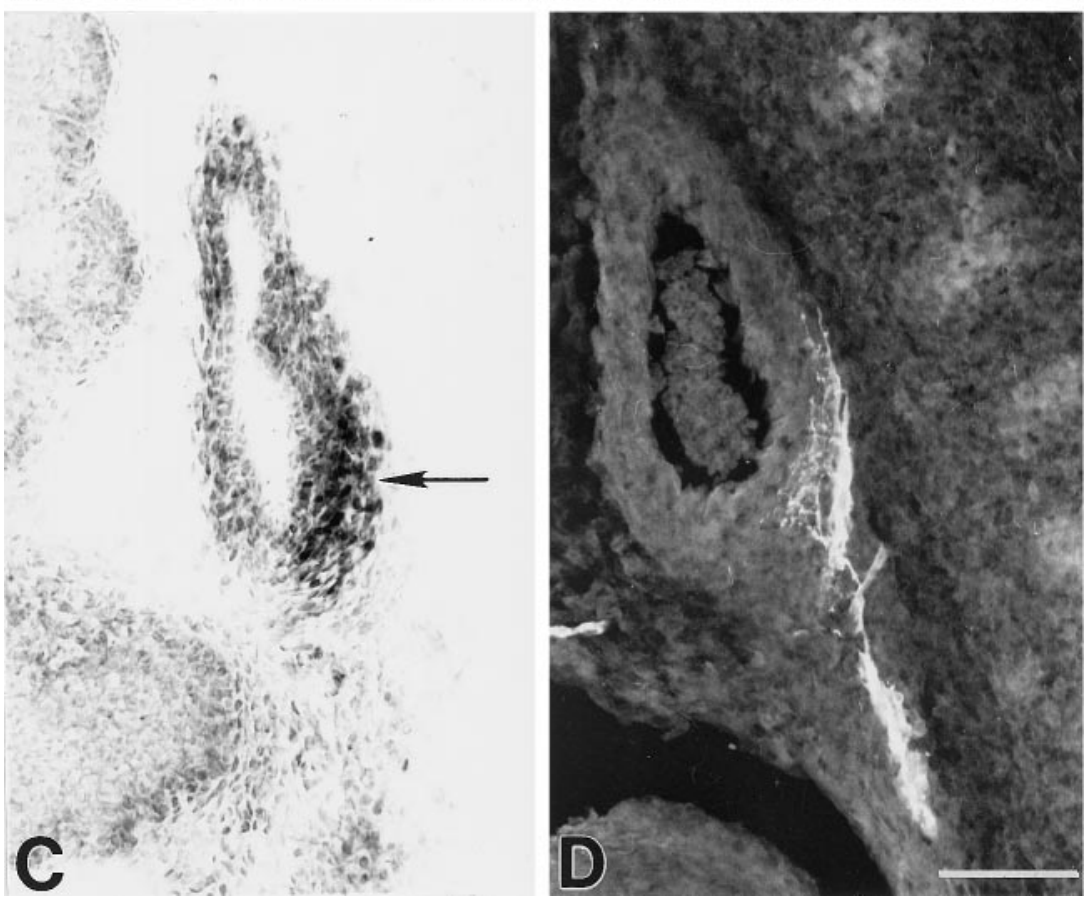

striking correspondence between the distribution of BDNF at each of these sites and the pattern of baroreceptor innervation revealed by PGP staining. In the right subclavian artery, for example, BDNF mRNA and protein (Figs. $4 A, C, 5 A, C$ ) and nerve fibers (Figs. $4 B, D, 5 B, D$ ) exhibited a circumferential distribution that was highly restricted to the origin of the artery at the bifurcation of the brachiocephalic trunk. A similar correspondence was evident between the distribution of nerve fibers and sites of high BDNF expression in the aortic arch (Fig. 6) and carotid sinus (Fig. 7). In addition to the baroreceptor regions of the cardiac outflow tract, BDNF mRNA and protein were also observed in some cells associated with the mesenchyme surrounding the pulmonary trunk (data not shown). BDNF mRNA and protein were undetectable in all other portions of the arterial tree, including the descending aorta, left subclavian artery, and common carotid arteries.

In addition to baroreceptor target tissues, visceral sensory neurons in the NPG also exhibited high levels of BDNF mRNA and protein (Figs.
$7 B, 8 A$, respectively), and BDNF-positive fibers were also found within the carotid sinus and carotid body (data not shown).

After E16.5, BDNF mRNA and protein levels in the vasculature declined sharply and could not be detected in the baroreceptor regions of the aortic arch, right subclavian artery, or carotid sinus by P0 (data not shown). In contrast, BDNF staining in NPG neurons increased after E16.5 and remained high at P0.

\section{Localization of BDNF mRNA and protein in the fetal carotid body}

The carotid body first appears at E13.5 as a condensation of undifferentiated mesenchymal cells associated with the third pharyngeal arch artery (Kondo, 1975). Initial innervation of the carotid body primordium also begins at this stage with the arrival of a small number of fibers from the carotid sinus nerve (Kondo, 1975; Hertzberg et al., 1994). BDNF mRNA and protein were both detectable within a small number of cells in the 


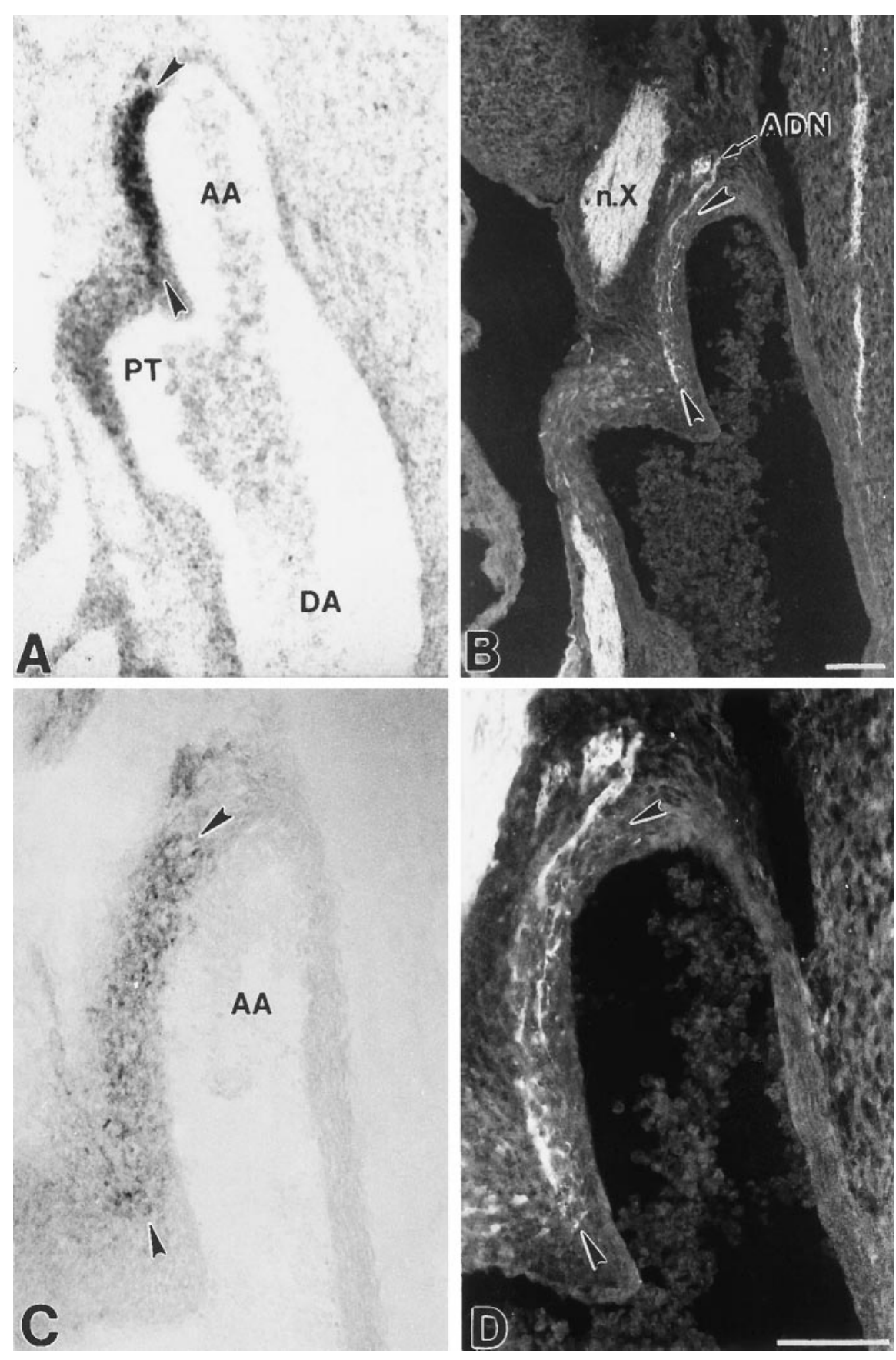

Figure 6. Localization of BDNF mRNA and protein, and baroreceptor fibers in the fetal aortic arch. Photomicrographs showing localization of BDNF mRNA $(A)$, BDNF immunoreactivity $(C)$, and PGP-stained baroreceptor fibers $(B, D)$ in the E16.5 aortic arch $(A A$; arrowheads $)$ at the level of the junction with the pulmonary trunk $(P T)$. Note the correspondence between the distribution of baroreceptor fibers ramifying in the outer wall of the arch ( $B$, arrowheads and at higher magnification in $D$ ) and BDNF mRNA and protein ( $A, C$, arrowheads). $A D N$, Aortic depressor nerve; $D A$, descending aorta; $n . X$, vagus nerve. Scale bars, $100 \mu \mathrm{m}$. carotid body primordium on E13.5 (data not shown). Expression in carotid body cells increased until E16.5 (Fig. 8A) and then rapidly declined to undetectable levels by birth. At the peak of BDNF protein expression on E16.5, levels of BDNF mRNA had already begun to decline to near background levels (compare Figs. $7 A, 8 A$ ).

In addition to intrinsic carotid body cells, nerve fibers innervating the carotid body also exhibited BDNF immunoreactivity, suggesting that chemoafferent neurons themselves contain BDNF. To approach this issue, we made use of the fact that a large subset of chemoafferent neurons in the petrosal ganglion (PG) is dopaminergic and thereby expresses the catecholamine-synthesizing enzyme TH. TH is not expressed by other subsets of PG neurons and is, therefore, a highly specific marker for the chemoafferent population (Katz and Black, 1986; Finley et al., 1992b). Double staining with BDNF and TH antibodies revealed that virtually all dopaminergic neurons in the P0 PG exhibit BDNF immunoreactivity (Fig. 9B,C), demonstrating that chemoafferent neurons themselves contain BDNF.

\section{Regulation of visceral afferent survival by endogenous BDNF}

The fact that PG neurons, including chemoafferents, express BDNF raised the possibility that endogenous BDNF could support survival of these neurons via an autocrine (Acheson et al., 1995) or paracrine mechanism (Robinson et al., 1996b). To test this possibility, dissociate cultures of E16.5 and P0 PG neurons were exposed to either BDNF (10 $\mathrm{ng} / \mathrm{ml})$ or a depolarizing concentration of $\mathrm{KCl}(40 \mathrm{mM})$ in the presence or absence of TrkB-Fc, an immunological reagent that inhibits TrkB activation by binding BDNF (Shelton et al., 1995). Very few E16.5 PG neurons survived in the absence of exogenous BDNF (Fig. 10 A, Control), and addition of BDNF resulted in a sevenfold increase in PG cell survival (Fig. 10A). $\mathrm{KCl}$ depolarization, a treatment that has previously been shown to release endogenous BDNF from hippocampal cells (Griesbeck et al., 1995), was as effective as exogenous BDNF in support- 

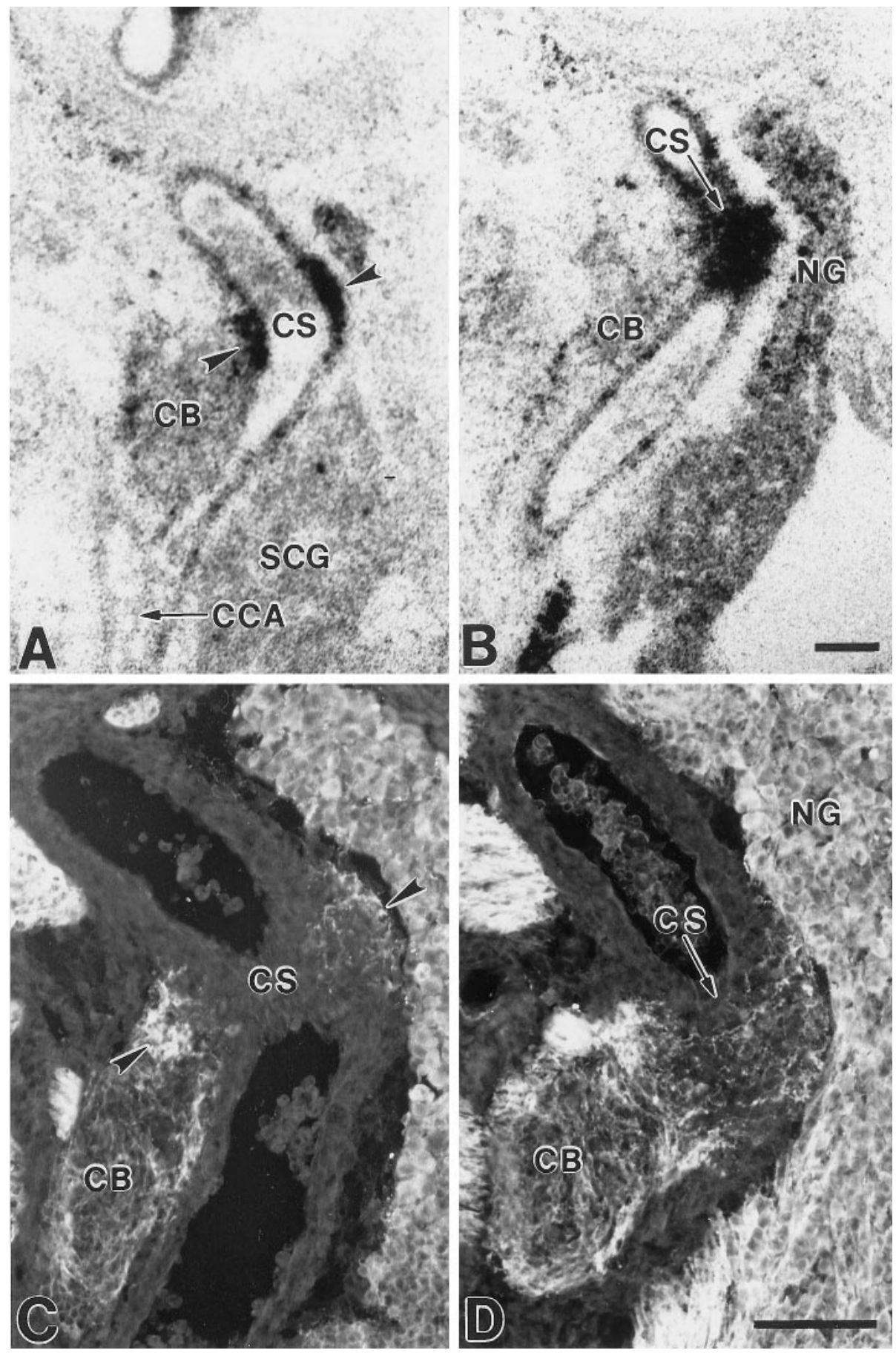

Figure 7. Localization of BDNF mRNA and baroreceptor fibers in the fetal carotid sinus. Photomicrographs showing the localization of BDNF mRNA $(A, B)$ and PGP-stained baroreceptor fibers $(C, D)$ in adjacent sagittal sections through the E16.5 carotid sinus $(C S) . A$ and $C$ pass through the lumen of the sinus and show BDNF mRNA $(A)$ and baroreceptor fibers $(C)$ in the adventitial layer of the sinus wall. $B$ and $D$ pass tangentially through the adventitial layer. BDNF mRNA labeling can also be seen over cells in the nodose ganglion $(N G)$ in $B$. Note the higher magnification in $C$ and $D$. Sections in $A$ and $B$ were counterstained with cresyl violet. $C B$, Carotid body; $C C A$, common carotid artery; $S C G$, superior cervical ganglion. Scale bars, $100 \mu \mathrm{m}$.

ing PG neuron survival, and this effect was significantly inhibited by TrkB-Fc (Fig. 10A). In contrast, in cultures of $\mathrm{P} 0$ neurons, neither BDNF nor $\mathrm{KCl}$ increased survival above control. Moreover, survival of $\mathrm{P} 0$ neurons, under all conditions, was unaffected by addition of TrkB-Fc (Fig. 10B), despite the fact that the cells exhibit abundant BDNF immunoreactivity in culture (Fig. 10C).

\section{DISCUSSION}

The present study demonstrates that BDNF is required for development of the arterial baroreceptor system. Based on the timing of BDNF expression in baroreceptor targets and the inability of fetal NPG neurons to survive in the absence of exogenous BDNF in culture, we propose that target-derived $\mathrm{BDNF}$ is required for baroreceptor survival during the onset of vascular innervation in the fetus. In addition, the fact that baroreceptor regions were completely devoid of innervation in newborn bdnf null mutants indicates that loss of BDNF cannot be compensated for by NT-4, the other high-affinity ligand for the BDNF receptor, TrkB (Berkemeier et al., 1991; Klein et al., 1992).

In conjunction with our previous studies demonstrating loss of carotid body afferent neurons in bdnf null mutants (Erickson et al., 1996), the present findings demonstrate that arterial chemoafferent and baroreceptor neurons share a common developmental requirement for $\mathrm{BDNF}$, despite the fact that they subserve markedly distinct sensory modalities. Chemoafferent 


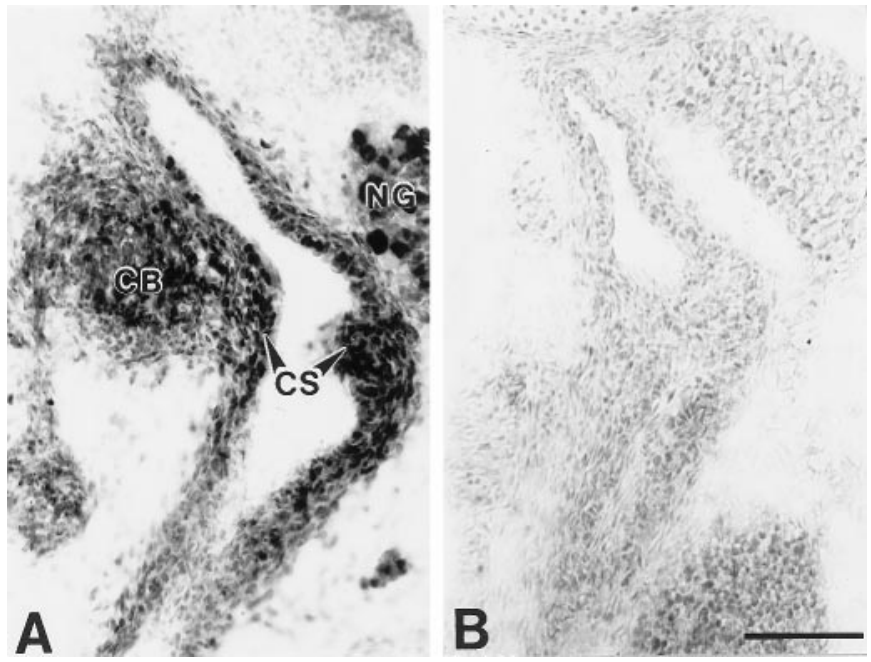

Figure 8. Localization of BDNF immunoreactivity in the fetal carotid sinus and carotid body. $A$, BDNF immunostaining of the carotid sinus $(C S)$, carotid body $(C B)$, and nodose ganglion $(N G)$. The level of this section is similar to that shown in Figure $7 A$. $B$, Control section, stained as in $A$, except that the primary antibody was omitted. Both sections were counterstained with cresyl violet. Scale bar, $100 \mu \mathrm{m}$.

neurons are activated transynaptically by glomus cell receptors in the carotid body that respond to changes in arterial $\mathrm{pO}_{2}, \mathrm{pCO}_{2}$, and $\mathrm{pH}$ (Eyzaguirre and Zapata, 1984; Gonzalez et al., 1994). In contrast, arterial baroafferents are mechanoreceptors that terminate as free endings, primarily in the vascular adventitia, and respond to deformations of the vessel wall caused by changes in arterial blood pressure (Abboud and Thames, 1983). The functional heterogeneity of BDNF-dependent vascular afferents contrasts with findings in the somatosensory system that neurotrophin dependencies are modality-specific (Snider, 1994; Lewin, 1996) and indicates that, in the visceral sensory system, growth factor requirements may be correlated with innervation of particular organ systems or tissues, rather than with particular sensory modalities. This is further supported by our finding that both chemo- and baroreceptor innervation appear to be unaffected in nt4 null mutants (Erickson et al., 1996; present study), despite the fact that $50 \%$ of NPG afferents die in these animals (Conover et al., 1995; Liu et al., 1995; Erickson et al., 1996).

The onset of BDNF mRNA and protein expression in both the carotid body and the cardiac outflow tract coincides with the arrival of sensory innervation. This is comparable to the sequence of events described for cutaneous sensory innervation in the mouse, in which initial expression of NGF mRNA and protein in the skin coincides with the initial appearance of afferent fibers (Davies et al., 1987). In contrast, BDNF mRNA expression in trigeminal targets in the mouse (Buchman and Davies, 1993) and in chick heart (Robinson et al., 1996a) precedes the earliest arrival of sensory axons, suggesting there is not an invariant relationship between the timing of afferent innervation and target expression of trophic factors in all systems. The period of BDNF expression in the carotid body and cardiac outflow tract, between E13.5-14.5 and E16.5, also overlaps the time at which NPG neurons are BDNF-dependent in vitro (present study), consistent with a role for BDNF as a classic, target-derived survival factor for chemoafferent and baroreceptor neurons during initial target innervation. Although BDNF expression in the carotid body falls markedly after E16.5 and is undetectable by P0, chemoafferent neurons remain target-dependent after birth (Hertzberg et al., 1994). These findings indicate that chemoafferent neurons probably switch their trophic requirements from BDNF to another target-derived factor or factors during late fetal development, as has been proposed for other populations of sensory neurons (Buchman and Davies, 1993).

In fetal animals, we observed some expression of BDNF in the mesenchyme surrounding the pulmonary trunk. Preliminary studies suggest this labeling is associated with neural crest-derived ectomesenchymal cells that participate in vessel wall formation (D. Katz, unpublished observations). In addition to its neurotrophic role, BDNF has been shown to stimulate vascular smooth muscle cell migration in vitro (Donovan et al., 1995). It is possible, therefore, that BDNF not only supports survival of vascular afferents during initial target innervation but also acts locally at some sites to influence vascular morphogenesis.

The fact that many NPG neurons express BDNF mRNA and protein at fetal stages raises the possibility that endogenous, in addition to target-derived, BDNF could support afferent survival
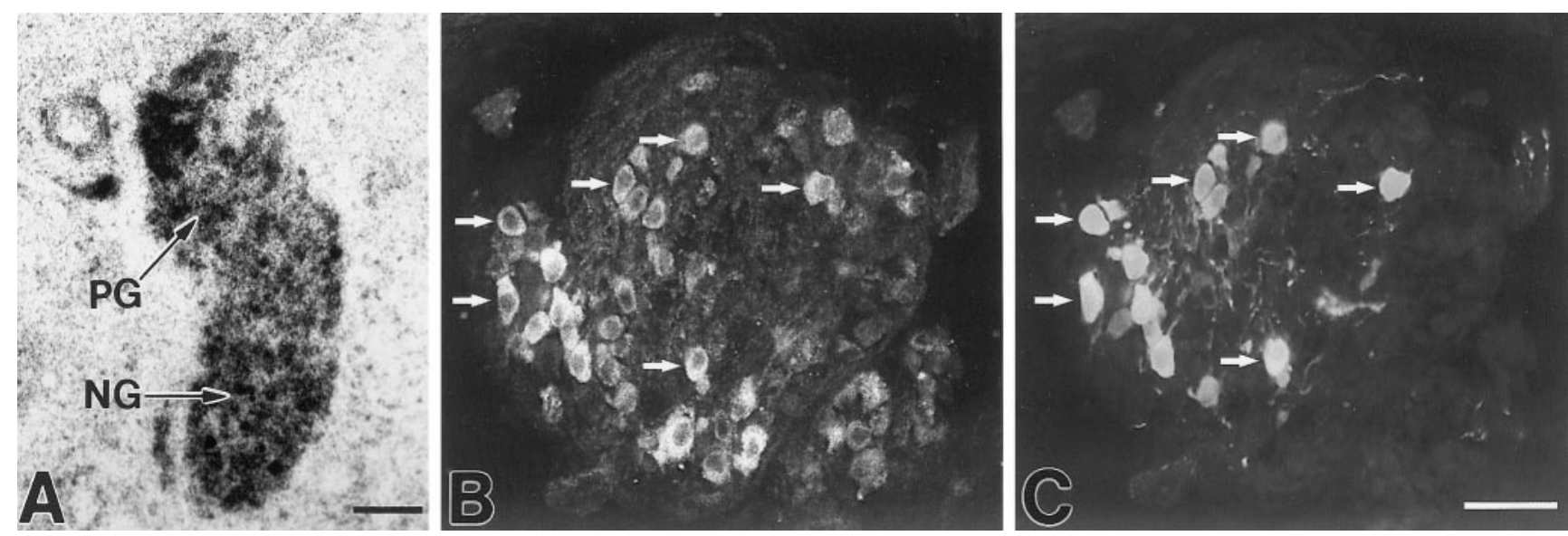

Figure 9. BDNF mRNA and protein expression in NPG neurons, including the chemoafferent population. $A$, Photomicrograph showing localization of BDNF mRNA in a section through the E16.5 NPG complex. $B, C$, Photomicrographs of a double-labeled section showing colocalization of BDNF $(B)$ and tyrosine hydroxylase $(C)$ immunoreactivity in ganglion cells in the newborn PG. Arrows indicate a subset of the double-labeled cells. TH is a specific marker for PG neurons that innervate the carotid body, and virtually all TH-positive ganglion cells are also BDNF-positive. Scale bars, $100 \mu \mathrm{m}$. 

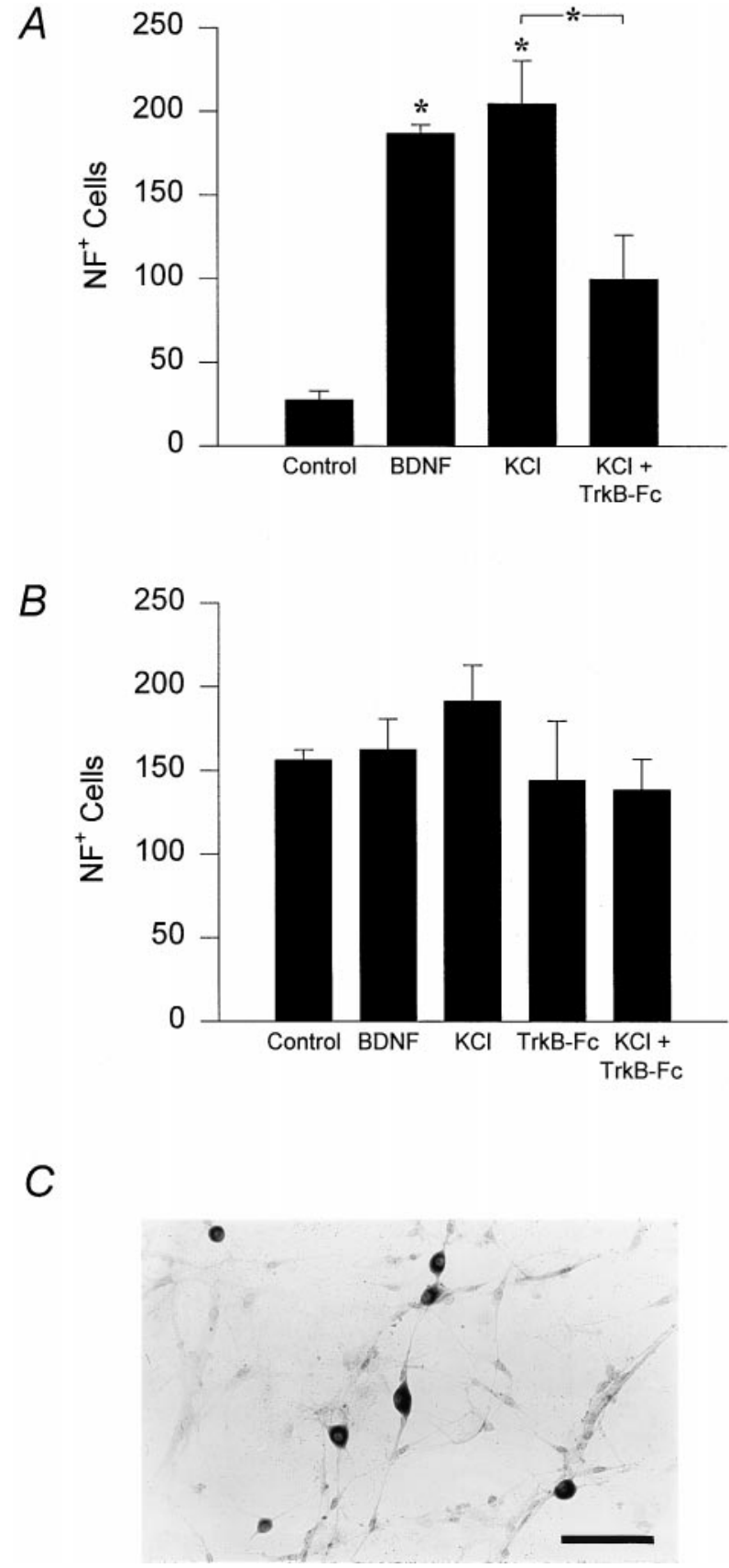

Figure 10. Endogenous BDNF supports survival of fetal PG neurons under depolarizing conditions in culture. Dissociate cultures of E16.5 $(A)$ or P0 $(B)$ PG neurons were grown for $3 \mathrm{~d}$ in either control medium or in the presence of BDNF $(10 \mathrm{ng} / \mathrm{ml}), 40 \mathrm{mM} \mathrm{KCl}$, TrkB-Fc alone $(5 \mu \mathrm{g} / \mathrm{ml})$, or $40 \mathrm{~mm} \mathrm{KCl}$ plus TrkB-Fc. Bars represent the number of neurofilamentpositive cells per ganglion plated \pm SEM. ANOVA was followed by Scheffe's multiple comparison procedure; ${ }^{*} p \leq 0.01$. $C$, P0 NPG neurons grown for $3 \mathrm{~d}$ in culture exhibit BDNF immunoreactivity. Non-neuronal cells, seen in the background, were not BDNF-positive. Scale bar, $100 \mu \mathrm{m}$.

by an autocrine (Acheson et al., 1995) or paracrine mechanism (Robinson et al., 1996b). However, in culture, few neurons survived in the absence of exogenous BDNF or potassium depolarization, indicating that endogenous BDNF was either not released under control conditions or was released at too low a concentration to support survival. However, even in explant cul- tures, in which autocrine or paracrine interactions would be maximized by the high cell density within the intact ganglion, the vast majority of E16.5 PG neurons are dependent on exogenous BDNF when grown under nondepolarizing conditions (Hertzberg et al., 1994). We think it likely, therefore, that targetderived, rather than endogenous BDNF, is responsible for supporting survival of fetal NPG neurons in vivo. However, because BDNF expression (Lindholm et al., 1994) and release (Ghosh et al., 1994) can be regulated by depolarizing stimuli, it is possible that PG neurons grown under nondepolarizing conditions in culture lose expression of endogenous BDNF and die as a result. Therefore, we cannot rule out the possibility that activitydependent cues play a role in vascular afferent development by promoting expression and release of endogenous BDNF in vivo. We consider it more likely, however, particularly in the newborn, that BDNF expressed by NPG neurons is related to a transynaptic signaling role, as has recently been proposed for other populations of BDNF-containing neurons (von Bartheld et al., 1996; Altar et al., 1997; Fawcett et al., 1998). Indeed, the BDNF receptor TrkB is expressed by neurons within the brainstem nucleus tractus solitarius (Yan et al., 1997a), the principal target of visceral afferent projections to the brain (Finley and Katz, 1992a). Baroreceptor afferents are already active in the fetus (Brinkman et al., 1969; Shinebourne et al., 1972; Itskovitz and Rudolph, 1982; Itskovitz et al., 1983; Yardley et al., 1983), raising the possibility that they release endogenous BDNF in an activitydependent manner during prenatal development in vivo. The fact that exogenous BDNF and $\mathrm{KCl}$ stimulation both increased survival of fetal, but not newborn, NPG neurons, is consistent with the finding that TrkB expression declines with age in the afferent neurons themselves (Zhou and Helke, 1996).

Our findings are in only limited agreement with the pattern of BDNF mRNA expression described by Scarisbrick et al. (1993) in the fetal vasculature. In that study, the authors reported that BDNF mRNA was localized to the aortic arch and descending aorta of fetal rats and that this pattern of expression persisted throughout life. These data are not supported by our finding that neither BDNF mRNA nor BDNF protein were detectable in the descending aorta at any stage and that BDNF expression in the aortic arch was restricted to the fetus. Moreover, the BDNF probe used by Scarisbrick et al. (1993) failed to detect BDNF mRNA in any of the other peripheral tissues known to synthesize BDNF, including the dorsal root ganglia, lingual taste buds, and vestibular sensory epithelium (Ernfors et al., 1992; Pirvola et al., 1992; Schecterson and Bothwell, 1992, 1994; Ylikoski et al., 1993; Nosrat and Olson, 1995), raising concern about the mRNA species identified in their study.

In conclusion, our results demonstrate a previously unrecognized role for BDNF in development of the arterial baroreceptor system and indicate that target-derived BDNF is particularly important for vascular afferent survival during initial stages of peripheral target innervation. These findings are consistent with a role for BDNF as a classic retrograde survival factor, similar to NGF in the somatosensory system (Davies et al., 1987). In addition, however, the fact that vascular afferents themselves express $\mathrm{BDNF}$ at later stages, when they no longer require BDNF for survival, indicates that BDNF may also play a transynaptic role in vascular afferent pathway development.

\section{REFERENCES}

Abboud F, Thames M (1983) Interaction of cardiovascular reflexes in circulatory control. In: Handbook of physiology. The cardiovascular 
system. Peripheral circulation and organ blood flow (Geiger SR, ed), pp 675-753. Bethesda, MD: American Physiological Society.

Acheson A, Conover JC, Fandl JP, DeChiara TM, Russell M, Thadani A, Squinto SP, Yancopoulos GD, Lindsay RM (1995) A BDNF autocrine loop in adult sensory neurons prevents cell death. Nature 374:450-453.

Altar CA, Cai N, Bliven T, Juhasz M, Conner JM, Acheson AL, Lindsay RM, Wiegand SJ (1997) Anterograde transport of brain-derived neurotrophic factor and its role in the brain. Nature 389:856-860.

Berkemeier LR, Winslow JW, Kaplan DR, Nikolics K, Goeddel DV, Rosenthal A (1991) Neurotrophin-5: a novel neurotrophic factor that activates trk and trkB. Neuron 7:857-866.

Brinkman CR, III, Lander C, Weston P, Assali NS (1969) Baroreceptor functions in the fetal lamb. Am J Physiol 217:1346-1351.

Buchman VL, Davies AM (1993) Different neurotrophins are expressed and act in a developmental sequence to promote the survival of embryonic sensory neurons. Development 118:989-1001.

Conner JM, Lauterborn JC, Yan Q, Gall CM, Varon S (1997) Distribution of brain-derived neurotrophic factor (BDNF) protein and mRNA in the normal adult rat CNS: evidence for anterograde axonal transport. J Neurosci 17:2295-2313.

Conover JC, Erickson JT, Katz DM, Bianchi LM, Poueymirou WT, McClain J, Pan L, Helgren M, Ip NY, Boland P, Friedman B, Wiegand S, Vejsada R, Kat AC, DeChiara TM, Yancopoulos GD (1995) Neuronal deficits, not involving motor neurons, in mice lacking BDNF and/or NT4. Nature 375:235-238.

Davies AM, Bandtlow C, Heumann R, Korsching S, Rohrer H, Thoenen $\mathrm{H}$ (1987) Timing and site of nerve growth factor synthesis in developing skin in relation to innervation and expression of the receptor. Nature 326:353-358.

Donovan MJ, Miranda RC, Kraemer R, McCaffrey TA, Tessarollo L, Mahadeo D, Sharif S, Kaplan DR, Tsoulfas P, Parada L, ToranAllerand CD, Hajjar DP, Hempstead BL (1995) Neurotrophin and neurotrophin receptors in vascular smooth muscle cells. Regulation of expression in response to injury. Am J Pathol 147:309-324.

ElShamy WM, Ernfors P (1997) Brain-derived neurotrophic factor, neurotrophin-3, and neurotrophin-4 complement and cooperate with each other sequentially during visceral neuron development. J Neurosci 17:8667-8675.

Erickson JT, Conover JC, Borday V, Champagnat J, Barbacid M, Yancopoulos, G, Katz DM (1996) Mice lacking brain-derived neurotrophic factor exhibit visceral sensory neuron losses distinct from mice lacking NT4 and display a severe developmental deficit in control of breathing. J Neurosci 16:5361-5371.

Ernfors P, Merlio J-P, Persson H (1992) Cells expressing mRNA for neurotrophins and their receptors during embryonic rat development. Eur J Neurosci 4:1140-1158.

Ernfors P, Lee K-F, Jaenisch R (1994a) Mice lacking brain-derived neurotrophic factor develop with sensory deficits. Nature 368:147-150.

Ernfors P, Lee K-F, Kucera J, Jaenisch R (1994b) Lack of neurotrophin-3 leads to deficiencies in the peripheral nervous system and loss of limb proprioceptive afferents. Cell 77:503-512.

Eyzaguirre C, Zapata P (1984) Perspectives in carotid body research. J Appl Physiol 57:931-957.

Farinas I, Jones KR, Backus C, Wang X-Y, Reichardt LF (1994) Severe sensory and sympathetic deficits in mice lacking neurotrophin-3. Nature 369:658-661.

Fawcett JP, Bamji SX, Causing CG, Aloyz R, Ase AR, Reader TA, McLean JH, Miller FD (1998) Functional evidence that BDNF is an anterograde neuronal trophic factor in the CNS. J Neurosci 18:2808-2821.

Finley JC, Katz DM (1992) The central organization of carotid body afferent projections to the brainstem of the rat. Brain Res 572:108-116.

Finley JC, Polak J, Katz DM (1992) Transmitter diversity in carotid body afferent neurons: dopaminergic and peptidergic phenotypes. Neuroscience 51:973-987.

Ghosh A, Carnahan J, Greenberg ME (1994) Requirement for BDNF in activity-dependent survival of cortical neurons. Science 263:1618-1623.

Gonzalez C, Almaraz L, Obeso A, Rigual R (1994) Carotid body chemoreceptors: From natural stimuli to sensory discharges. Physiol Rev 74:829-898.

Griesbeck O, Blochl A, Carnahan JF, Nawa H, Thoenen H (1995) Characterization of brain-derived neurotrophic factor (BDNF) secretion from hippocampal neurons. Soc Neurosci Abstr 21:1046.

Hertzberg T, Fan G, Finley JCW, Erickson JT, Katz DM (1994) BDNF supports mammalian chemoafferent neurons in vitro and following peripheral target removal in vivo. Dev Biol 166:801-811.

Heymans C, Neil E (1958) Reflexogenic areas of the cardiovascular system. Boston, MA: Little, Brown.

Hofer M, Pagliusi SR, Hohn A, Leibrock J, Barde YA (1990) Regional distribution of brain-derived neurotrophic factor mRNA in the adult mouse brain. EMBO J 9:2459-2464.

Itskovitz J, LaGamma EF, Rudolph AM (1983) Baroreflex control of the circulation in chronically instrumented fetal lambs. Circ Res 52:589-596.

Itskovitz J, Rudolph AM (1982) Denervation of arterial chemoreceptors and baroreceptors in fetal lambs in utero. Am J Physiol 242:H916-H920.

Jones KR, Farinas I, Backus C, Reichardt LF (1994) Targeted disruption of the BDNF gene perturbs brain and sensory neuron development but not motor neuron development. Cell 76:989-999.

Katz DM, Black IB (1986) Expression and regulation of catecholaminergic traits in primary sensory neurons: relationship to target innervation in vivo. J Neurosci 6:983-989.

Katz DM, Karten HJ (1985) Topographic representation of visceral target organs within the dorsal motor nucleus of the vagus nerve of the pigeon Columba livia. J Comp Neurol 242:397-414.

Klein R, Lamballe F, Bryant S, Barbacid M (1992) The trkB tyrosine protein kinase is a receptor for neurotrophin-4. Neuron 8:947-956.

Kondo H (1975) A light and electron microscopic study on the embryonic development of the rat carotid body. Am J Anat 144:275-293.

Lewin GR (1996) Neurotrophins and the specification of neuronal phenotype. Philos Trans R Soc Lond B Biol Sci 351:405-411.

Lindholm D, Castren E, Berzaghi M, Blochl A, Thoenen H (1994) Activity-dependent and hormonal regulation of neurotrophin mRNA levels in the brain-implications for neuronal plasticity. J Neurobiol 25:1362-1372.

Liu X, Ernfors P, Wu H, Jaenisch R (1995) Sensory but not motor neuron deficits in mice lacking NT4 and BDNF. Nature 375:238-241.

Mains RE, Patterson PH (1973) Primary cultures of dissociated sympathetic neurons. I. Establishment of long-term growth in culture and studies of differentiated properties. J Cell Biol 59:329-345.

Maisonpierre PC, LeBeau MM, Espinosa III R, Ip NY, Belluscio L, de la Moute SM, Squinto S, Furth ME, Yancopoulos GD (1991) Human and rat brain-derived neurotrophic factor and neurotrophin-3: gene structures, distributions, and chromosomal localizations. Genomics 10: $558-568$.

Moore MW, Klein RD, Farinas I, Sauer H, Armanini M, Phillips H, Reichardt LF, Ryan AM, Carver-Moore K, Rosenthal A (1996) Renal and neuronal abnormalities in mice lacking GDNF. Nature 382:76-79.

Nosrat CA, Olson L (1995) Brain-derived neurotrophic factor mRNA is expressed in the developing taste bud-bearing tongue papillae of rat. J Comp Neurol 360:698-704.

Pirvola U, Ylikoski J, Palgi J, Lehtonen E, Arumae U, Saarma M (1992) Brain-derived neurotrophic factor and neurotrophin 3 mRNAs in the peripheral target fields of developing inner ear ganglia. Proc Natl Acad Sci USA 89:9915-9919.

Robinson M, Adu J, Davies AM (1996a) Timing and regulation of trkB and BDNF mRNA expression in placode-derived sensory neurons and their targets. Eur J Neurosci 8:2399-2406.

Robinson M, Buj-Bello A, Davies AM (1996b) Paracrine interactions of BDNF involving NGF-dependent embryonic sensory neurons. Mol Cell Neurosci 7:143-151.

Scarisbrick IA, Jones EG, Isackson PJ (1993) Coexpression of mRNAs for NGF, BDNF, and NT-3 in the cardiovascular system of the pre- and postnatal rat. J Neurosci 13:875-893.

Schecterson LC, Bothwell M (1992) Novel roles for neurotrophins are suggested by BDNF and NT-3 mRNA expression in developing neurons. Neuron 9:449-463.

Schecterson LC, Bothwell M (1994) Neurotrophin and neurotrophin receptor mRNA expression in developing inner ear. Hear Res 73:92-100.

Shelton DL, Sutherland J, Gripp J, Camerato T, Armanini MP, Phillips HS, Carroll K, Spencer SD, Levinson AD (1995) Human trks: molecular cloning, tissue distribution, and expression of extracellular domain immunoadhesins. J Neurosci 15:477-491.

Shinebourne EA, Vapaavuori EK, Williams RL, Heymann MA, Rudolph AM (1972) Development of baroreflex activity in unanesthesized fetal and neonatal lambs. Circ Res 31:710-718. 
Snider WD (1994) Functions of the neurotrophins during nervous system development: what the knockouts are teaching us. Cell 77:627-638. von Bartheld CS, Byers MR, Williams R, Bothwell M (1996) Anterograde transport of neurotrophins and axodendritic transfer in the developing visual system. Nature 379:830-833.

Wetmore C, Olson L (1995) Neuronal and nonneuronal expression of neurotrophins and their receptors in sensory and sympathetic ganglia suggest new intercellular trophic interactions. J Comp Neurol 353:143-159.

Wetmore C, Ernfors P, Persson H, Olson L (1990) Localization of brain-derived neurotrophic factor mRNA to neurons in the brain by in situ hybridization. Exp Neurol 109:141-152.

Yan Q, Radeke MJ, Matheson CR, Talvenheimo J, Welcher AA, Feinstein SC (1997a) Immunocytochemical localization of TrkB in the central nervous system of the adult rat. J Comp Neurol 378:135-157.

Yan Q, Rosenfeld RD, Matheson CR, Hawkins N, Lopez OT, Bennet D,
Welcher AA (1997b) Expression of brain-derived neurotrophic factor $(\mathrm{BDNF})$ protein in the adult rat central nervous system. Neuroscience 78:431-48.

Yardley RW, Bowes G, Wilkinson M, Cannata JP, Maloney JE, Ritchie BC, Walker AM (1983) Increased arterial pressure variability after arterial baroreceptor denervation in fetal lambs. Circ Res 52:580-588.

Ylikoski J, Pirvola U, Moshnyakov M, Palgi J, Arumae U, Saarma M (1993) Expression patterns of neurotrophin and their receptor mRNAs in the rat inner ear. Hear Res 65:69-78.

Zhou H, Helke CJ (1996) Presence and localization of neurotrophin receptor tyrosine kinase (TrkA, TrkB, TrkC) mRNAs in visceral afferent neurons of the nodose and petrosal ganglia. Mol Brain Res 38:63-70.

Zhou XF, Chie ET, Rush RA (1998) Distribution of brain-derived neurotrophic factor in cranial and spinal ganglia. Exp Neurol 149: 237-242. 